https://doi.org/10.21122/1029-7448-2020-63-5-441-449

UDC 629.7

\title{
An Adaptive Maximum Power Output Sustaining System for a Photovoltaic Power Plant Based on a Robust Predictive Control Approach
}

\author{
I. Elzein ${ }^{1)}$, Yu. N. Petrenko1) \\ ${ }^{1)}$ Belarusian National Technical University (Minsk, Republic of Belarus) \\ (c) Белорусский национальный технический университет, 2020 \\ Belarusian National Technical University, 2020
}

\begin{abstract}
Photovoltaic power plants have non-linear voltage-current characteristic, with specific maximum power point, which depends on operating conditions, viz. irradiation and temperature. In targeting the maximum power, it is by far known that the photovoltaic arrays have to operate at the maximum power point despite unpredicted weather changes. For this reason the controllers of all photovoltaic power electronic converters employ some method for maximum power point tracking. This paper makes an emphasis on model predictive controller as a control method for controlling the maximum power point tracking through the utilization of the well-known algorithm namely the Perturb and Observe technique. Further, during the advanced stages of this research study, the model will compare the results obtained for tracking the maximum power point from model predictive controller and a PID-controller as they are integrated Perturb and Observe algorithm. The obtained results will verify that the adaptive PID-controller Perturb and Observe algorithm has limitation for tracking the precise MPP during the transient insulation conditions. As compared to the proposed adaptive/modified model predictive controller for Perturb and Observe algorithm we illustrate that by adopting this method we will get to establish more accurate and efficient results of the obtained power in any dynamic environmental conditions: advantages as on regulation time (six times under the accepted experimental conditions) and by the number of fluctuations.
\end{abstract}

Keywords: photovoltaic power plants, maximum power output sustaining, Perturb and Observe algorithm, PID-controllers, proactive management model, computer simulation

For citation: Elzein I., Petrenko Yu. N. (2020) An Adaptive Maximum Power Output Sustaining System for a Photovoltaic Power Plant Based on a Robust Predictive Control Approach. Energetika. Proc. CIS Higher Educ. Inst. and Power Eng. Assoc. 63 (5), 441-449. https://doi.org/10. 21122/1029-7448-2020-63-5-441-449

\section{Адаптивная система обеспечения максимальной выходной мощности фотоэлектрической станции на основе робастного прогнозного управления}

\author{
И. Элзейн ${ }^{1)}$, Ю. Н. Петренко ${ }^{1)}$
}

${ }^{1)}$ Belarusian National Technical University (Minsk, Republic of Belarus)

Реферат. Фотоэлектрические станции (ФЭС) характеризуются нелинейной зависимостью выходного тока и напряжения с уникальной точкой максимальной выходной мощности (MBM),

\begin{tabular}{ll}
\hline Адрес для переписки & Address for correspondence \\
Петренко Юрий Николаевич & Petrenko Yuriy N. \\
Белорусский национальный технический университет & Belarusian National Technical University \\
ул. Ф. Скорины, 25/3 & 25/3, F. Skoriny str., \\
220014, г. Минск, Республика Беларусь & 220014 , Minsk, Republic of Belarus \\
Тел.: +375 17 266-26-61 & Tel.: +375 17 266-26-61 \\
ypetrenko@bntu.by & ypetrenko@bntu.by \\
\hline
\end{tabular}


зависящей от условий эксплуатации - температуры и уровня солнечной радиации. Поэтому для повышения эффективности фотоэлектрического преобразования необходимо обеспечить работу ФЭС в точке МВМ. Это достигается применением соответствующих алгоритмов управления, наиболее известными из которых являются P\&O («возмущение и наблюдение»). Эти алгоритмы основаны на изменении напряжения постоянного тока ФЭС с помощью преобразователя постоянного тока (регулятора), выходное напряжение которого должно изменяться по определенному закону с изменением условий эксплуатации. При этом используются регуляторы: пропорциональные (П), интегральные (И), дифференциальные (Д) или чаще всего их комбинации ПИД. В статье исследуется эффективность применения регулятора с прогнозным адаптивным управлением (МРС). Посредством численных экспериментов на разработанной имитационной модели показано, что ПИД-регуляторы в интеграции с $\mathrm{P} \& \mathrm{O}$ и INC алгоритмами не обеспечивают достаточно быстрой реакции при изменении условий внешней среды. В то же время МРC в сочетании с $\mathrm{P \& O}$ имеет преимущества как по времени регулирования (в шесть раз при принятых условиях эксперимента), так и по количеству колебаний.

Ключевые слова: фотоэлектрическая станция, обеспечение максимальной выходной мощности, алгоритм «возмущение и наблюдение», ПИД-контроллеры, модель упреждающего управления, компьютерное моделирование.

Для цитирования: Элзейн, И. Адаптивная система обеспечения максимальной выходной мощности фотоэлектрической станции на основе робастного прогнозного управления / И. Элзейн, Ю. Н. Петренко // Энергетика. Изв. высш. учеб. заведений и энерг. объединений СНГ. 2020. Т. 63, № 5. C. 441-449. https://doi.org/10.21122/1029-7448-2020-63-5-441-449

\section{Introduction}

Driven by anxieties over energy saving and environmental protection and energy accessibility, the installation of photovoltaic (PV) energy-productions systems has been noticeably enlarged during the last years. The decreasing prices of PV modules and more highly efficient power conversion systems have supported that trend by augmenting the economic viability of the installed PV systems [1, 2].

Renewable energies like solar and wind are environmentally friendly sustainable sources of energy. One of the most efficient and well-accepted renewable energy sources is photovoltaic systems [3]. For these reasons the research in the field of PV application, based on modeling, including application of modern means like SimPowerSystems and MatLab/Simulink is conducted in many countries [4]. Adequate and efficient maximum power point tracking (MPPT) is needed, due to the nonlinearity of PV sources. Several techniques have been proposed for maximum power tracking [5-7]. MPPT algorithms have to be stable, robust, fast, and efficient. Due to fast changes in environmental conditions, MPPT algorithms should respond quickly to changes in atmospheric conditions [8-10].

The Perturb and Observe (P\&O) method is one of the most commonly used techniques $[11,12]$ due to its simplicity, ease of implementation, and good performance. Nevertheless, it is observed that there are some power losses due to the perturbation, and that it fails to track the power under fast varying atmospheric conditions [13]. Perturbation determines the system response and the steady state error. For lower oscillations a small perturb value is required, while large perturb values cause higher oscillations. Unfortunately, smaller perturb values result in a slower response. One solution is to use a perturb value that varies, as proposed by the authors of [14-16].

Finite-set model predictive control (MPC) is a promising control technique [17-19]. MPC does not involve any complex control loops. It deliberates the controlled plant as a finite set of linear models, each demonstrating a physical switching state. The controlled variable is predicted in every switching state. The control is assessed and applied at intermediate instants of time. This results in a variable switching frequency where the maximum switching frequency 
is limited to half the sampling frequency. Under a variable switching frequency, it is problematic to control electromagnetic interference (EMI) and to preserve a desired output voltage quality [20].

\section{Perturbation and Observation algorithm}

The Perturbation and Observation $(\mathrm{P} \& \mathrm{O})$ algorithm is one of most widely used methods for controlling DC/DC converters due to its easy implementation. This algorithm works based on this idea when the PV module is not working in MPPT point, the operating voltage of the module is disturbed periodically in small voltage $V$ through DC-DC converter duty cycle.

Then the change on the output power $\Delta P$ of photovoltaic is measured. If $\Delta P>0$, the operating point is near to the maximum power point (MPP) and same disturbance of $V$ will occur in the same direction as the previous one. However, if $\Delta P<0$, the system has moved away from MPP and next disturbance will occur in the opposite direction.

Once the MPP has been reached, the P\&O makes the point of operation of the photovoltaic module to work around it. However, if $\Delta P<0$, the system has moved away from MPP and next disturbance will occur at opposite direction. Once the MPP has been reached, the P\&O makes the point of operation of the photovoltaic module to work around it [21-23].

Fig. 1 shows the Perturb and Observe algorithm and how does it function in perturbing the step size. Knowing that $V$, and $I$ are the voltage, and current at previous and current time and this is the same for the power $P$.

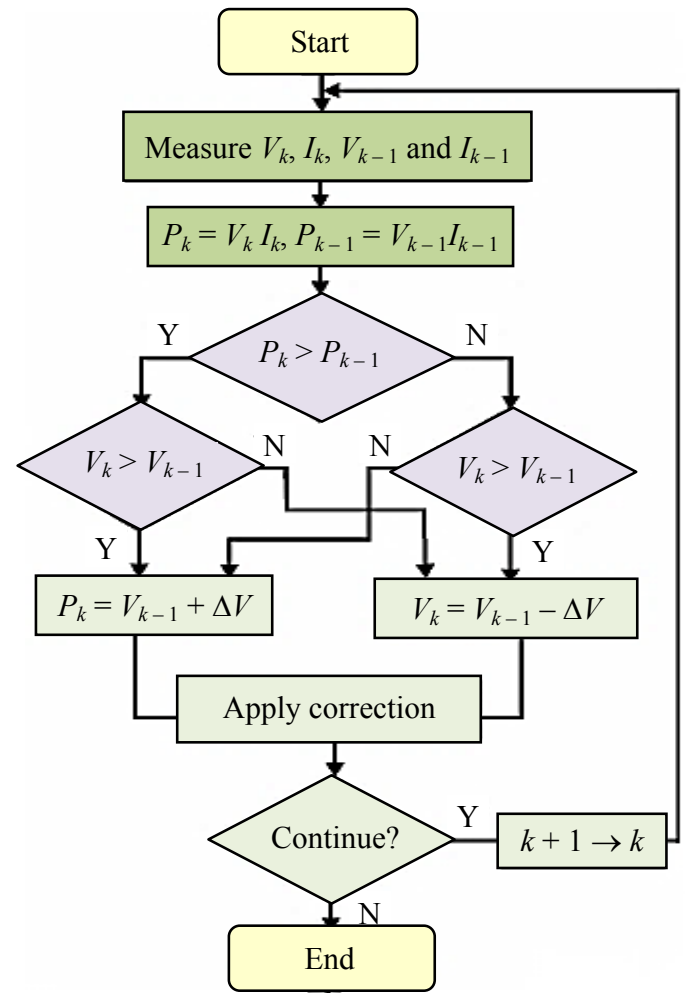

Fig. 1. Flowchart of the maximum power point tracking Perturb \& Observe algorithm 


\section{Model predictive controller scheme}

The ultimate achievement over the next discussions is to improve the operation of the $\mathrm{P} \& \mathrm{O}$ algorithm. This can be performed through the usage of predicting the future behavior of the desired control variables until a predefined horizon in time. As we utilize the predicted variables, the switching state will be obtained through minimization of a cost function [24-26].

$\mathrm{P} \& \mathrm{O}$ determines the reference current for the MPC which determines the next switching state. This technique predicts the error of the next sampling time and based on optimization of the cost function $g$. The inputs to the predictive controller are the PV system current, voltage, and the reference current. By deriving the discrete time set of equations, the behavior of control variable can be predicted at next sampling time $k$. The proposed methodology is based on the fact that the slope of the PV array power curve is zero at the predicted MPP, positive on the left and negative on the right of the predicted MPP. Predicted behavior of control variables at the next sampling time $k+1$ can be described by a discrete-time set of equations by the following [27-29]:

- when switch is "ON":

$$
\begin{gathered}
I_{\mathrm{PV}}(k+1)=T_{s} / L V V_{\mathrm{PV}}(k)+I_{\mathrm{PV}}(k) ; \\
V_{c}(k+1)=\left(1-T_{s} / R C\right) V_{c}(k),
\end{gathered}
$$

where $I_{\mathrm{PV}}$ - photovoltaic current; $T_{s}$ - switching period; $V_{\mathrm{PV}}$ - photovoltaic voltage; $V_{c}$ - capacitance voltage; $R$ - resistance; $C$ - capacitor;

- when switch is "OFF":

$$
\begin{gathered}
I_{\mathrm{PV}}(k+1)=I_{\mathrm{PV}}(k)-T_{s} / \ln V_{c}(k) ; \\
g=f(x(k), u(k), \ldots, u(k+N)) .
\end{gathered}
$$

The cost function can be obtained as per the following

$$
g_{s}=0,1\left|I_{\mathrm{PV}, s}=0,1(k+1)-I_{\text {ref }}\right|,
$$

where $g_{s}-$ cost function; $I_{\mathrm{PV}, s}-$ photovoltaic current; $I_{r e f}$ - reference current.

The objective is to minimize the cost function $g$. The final switching state for MPPT can be determined using procedure illustrated in Fig. 2. Model predictive control approach is used for controlling the input current of the DC-DC converter [30].

Knowing that the $V_{\mathrm{PV}}$ and $I_{\mathrm{PV}}$ are the voltage and current of the photovoltaic station and $I_{r e f}$ is the reference current. The cost function is defined as $g_{s}$.

Model predictive control approach is used for controlling the input current of the DC-DC converter. The designed controller should provide the capability of tracking the reference current generated by the suggested MPPT method with satisfactory dynamic and steady-state performances. Based on the MPC concept, the future behavior of the input current should be predicted separately for each of the two different switching states of the converter using appropriate equations [31-33]. 


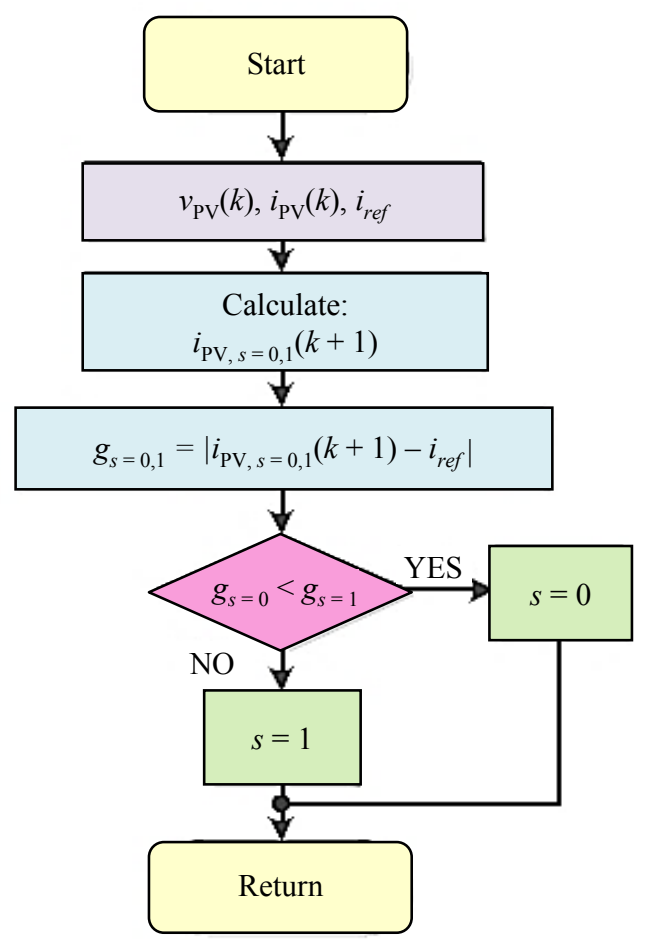

Fig. 2. Model predictive control process for the maximum power point tracking $I_{\mathrm{PV}}^{\prime}$

Fig. 3 depicts the proposed control scheme for a stand-alone PV system. In this system, the PV panel is coupled directly to a boost converter, used to realize the MPPT operation with a resistive load.

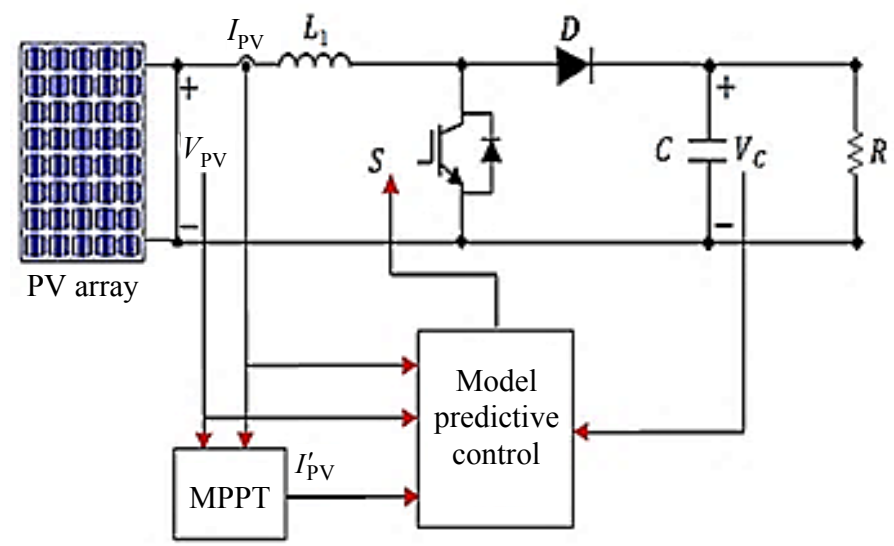

Fig. 3. Photovoltaic station control scheme using model predictive control: $I_{\mathrm{PV}}$ - photovoltaic current; $V_{\mathrm{PV}}$ - photovoltaic voltage; $D$ - diode; $V_{c}$ - capacitor voltage

The MPPT algorithm uses PV voltage and current measurements to generate the PV output current reference. Then, a predictive current controller is aimed to regulate the PV current according to the reference current. Simulations 
have been conducted and an experimental validation has been achieved to confirm the feasibility and performance improvement of the proposed control scheme $[34,35]$.

\section{Implementation and results}

From the orientation of the system above we will make simulations based on using a Kyocera KC-200-GT which can produce a maximum power of around $200 \mathrm{~W}$. The technical data sheet from the manufacturer is listed below in Tab. 1.

Technical datasheet for Kyocera solar panel

\begin{tabular}{|l|c|}
\hline \multicolumn{1}{|c|}{ Parameter name } & PV parameters value \\
\hline Open-circuit voltage $V_{o c}$ & $32.9 \mathrm{~V}$ \\
\hline Optimum operating voltage $V_{m p}$ & $26.4 \mathrm{~V}$ \\
\hline Short-circuit current $I_{s c}$ & $8.21 \mathrm{~A}$ \\
\hline PV current $I_{\mathrm{PV}}$ & $8.213 \mathrm{~A}$ \\
\hline Optimum operating current $I_{m p}$ & $7.95 \mathrm{~A}$ \\
\hline Maximum power at STC $P_{\max }$ & $200 \mathrm{~W}$ \\
\hline
\end{tabular}

According to the following figures we generated through the Simulink the simulations for adaptive $\mathrm{P} \& \mathrm{O}$ using PID-controller and compared with $\mathrm{P} \& \mathrm{O}$ using MPC controller. The irradiance that was selected for both controllers was set to $1000 \mathrm{~W} / \mathrm{m}^{2}$ at a constant temperature of $25{ }^{\circ} \mathrm{C}$. As shown in Fig. 4, we observed that the PID-controller as used as a controller for the $\mathrm{P} \& \mathrm{O}$ was oscillating during the period of time up to roughly $0.6 \mathrm{~s}$ and a fluctuation in the power curve was observed as it was trying to make the corrective measures in tracking the maximum powerpoint which was supposed to be $200 \mathrm{~W}$.

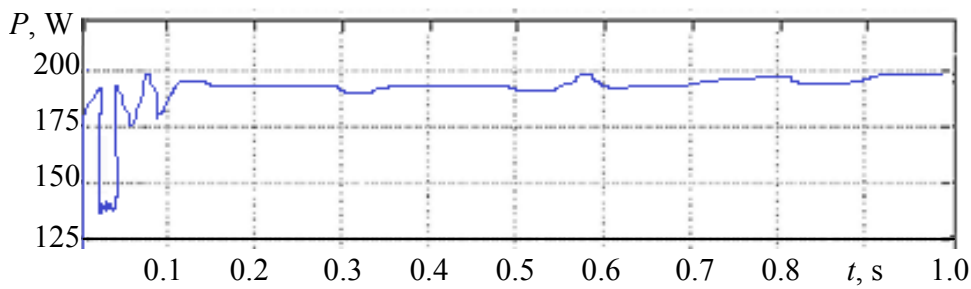

Fig. 4. Perturb and Observe using PID-controller - STC condition

Eventually the controller was almost trying to reach its detection goal of reaching the maximum power point MPP between the time frame of $0.65 \mathrm{~s}$ onwards with lower oscillation rates as detecting and tracking the MPP. As comparing the results of Fig. 4 to those in Fig. 5 where we applied an 
adaptive $\mathrm{P} \& \mathrm{O}$ using MPC we can conclude that the MPC was able and being faster in tracking the MPP at a time frame of 0.02 which as compared to those results from the PID-controller we see that MPC was more reliable with faster response time to extract the most efficient power of the system and thus being faster by almost six times in reaching the MPP at power factor of $200 \mathrm{~W}$. Oscillation through the utilization of MPC was suppressed as proved in Fig. 5.

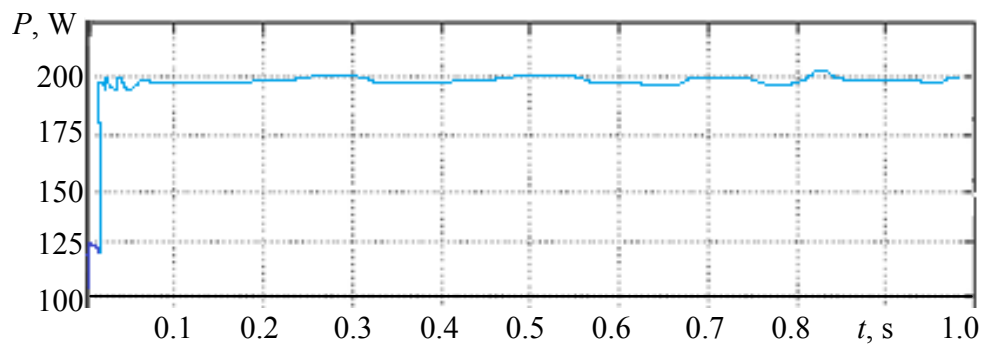

Fig. 5. Perturb and Observe using model predictive controller - STC conditions

\section{CONCLUSION}

In this paper we introduced a comparative scenario to use an adaptive Perturb and Observe algorithm for both PID and model predictive controller controllers. It was noticed that adapting an model predictive controller to the Perturb and Observe algorithm produced better results in tracking the maximum power point and reaching it in a very fast responsive time and thus made the extraction of power more efficient under fixed and fast environmental weather conditions. The overall performance using model predictive controller was better than that of PID and the simulations were showing these attestations as we used the algorithms Perturb and Observe.

\section{REFERENCES}

1. Khroustalev B. M., Pilipenko V. M., Danilevsky L. N., Nguyen Thuy Nga (2014) On Problem in Development of House Building Construction with Minimum Power Resources Consumption. Energetika. Izvestiya Vysshikh Uchebnykh Zavedenii i Energeticheskikh Ob'edinenii $S N G=$ Energetika. Proceedings of the CIS Higher Education Institutions and Power Engineering Associations, (5), 45-60 (in Russian).

2. Kundas C. P., Poznyak S. S., Shenets L. V. (2009) Renewable Sources of Power. Minsk, International Sakharov Environmental Institute of Belarusian State University. 315 (in Russian).

3. Maronchuk I. I., Sanikovich D. D., Mironchuk V. I. (2019) Solar Cells: Current State and Development Prospects. Energetika. Izvestiya Vysshikh Uchebnykh Zavedenii i Energeticheskikh Ob'edinenii $S N G=$ Energetika. Proceedings of the CIS Higher Education Institutions and Power Engineering Associations, 62 (2), 105-123. https://doi.org/10.21122/1029-7448-201962-2-105-123 (in Russian).

4. Zalizny D. I. (2019) Model of a Photovoltaic Cell for the MatLab/Simulink SimPowerSystems Library. Energetika. Izvestiya Vysshikh Uchebnykh Zavedenii i Energeticheskikh Ob'edinenii $S N G=$ Energetika. Proceedings of the CIS Higher Education Institutions and Power Engi- 
neering Associations, 62 (2), 135-145. https://doi.org/10.21122/1029-7448-2019-62-2-135-145 (in Russian).

5. Veerachary M., Senjyu T., Uezato K. (2020) Voltage-Based Maximum Power Point Tracking Control of PV System. IEEE Transactions on Aerospace and Electronic Systems, 38 (1), 262-270. https://doi.org/10.1109/7.993245.

6. Hau C., Shen C. (1998) Comparative Study of Peak Power Tracking Techniques for Solar Storage System. APEC '98 Thirteenth Annual Applied Power Electronics Conference and Exposition. https://doi.org/10.1109/apec.1998.653972.

7. Onat N. (2010) Recent Developments in Maximum Power Point Tracking Technologies for Photovoltaic Systems. International Journal of Photoenergy, 2010, 245316. https://doi.org/10. $1155 / 2010 / 245316$.

8. Nemsi S., Barazane L., Diaf S., Malek A. (2013) Comparative Study between Two Maximum Power Point Tracking Techniques for Photovoltaic System. Revue des Energies Renouvelables, 16 (4), 773-782.

9. Elzein I. (2015) Maximum Power Point Tracking System for Photovoltaic Station: a Review. Sistemnyi Analiz i Prikladnaya Informatika = System Analysis and Applied Information, (3), $15-20$.

10. Estram T., Chapman P. L. (2007) Comparison of Photovoltaic Array Maximum Power Point Tracking Techniques. IEEE Transactions on Energy Conversion, 22 (2), 439-449. https://doi. org/10.1109/tec.2006.874230.

11. Petrenko Y. N., Tresch A. M. (2013) Independent Control System of Photoelectric Installation. Nauka i Tekhnika = Science \& Technique, (1), 53-56 (in Russian).

12. Subudhi B., Pradhan R. (2013) A Comparative Study on Maximum Power Point Tracking Techniques for Photovoltaic Power Systems. IEEE Transactions on Sustainable Energy, 4 (1), 89-98. https://doi.org/10.1109/tste.2012.2202294.

13. Elzein I., Petrenko Y. N. (2015) Model Predictive Control for Photovoltaic Station Maximum Power Point Tracking System. Sistemnyi Analiz i Prikladnaya Informatika $=$ System Analysis and Applied Information, (4), 17-25.

14. Elzein I., Kurdi M., Dadykin A. (2017) Model Predictive Control for Positioning and Navigation of Mobile Robot with Cooperation of UAV. Communications on Applied Electronics, 6 (7), 17-25. https://doi.org/10.5120/cae2017652506.

15. Sotnikova M., Veremey E. (2013) Dynamic Positioning Based on Nonlinear Model Predictive Control. IFAC Proceedings Volumes, 46 (33), 37-42. https://doi.org/10.3182/20130918-4-jp3022.00058 .

16. Elzein I., Petrenko Y. N. An Integration of A Predictive Control Model and MPPT for PV Station. 2016 International Conference on Smart Systems and Technologies (SST). https://doi. org/10.1109/sst.2016.7765673.

17. Xiao W., Lind M. G. J., Dunford W. G., Capel A. (2006) Real-Time Identification of Optimal Operating Points in Photovoltaic Power Systems. IEEE Transactions on Industrial Electronics, 53 (4), 86-91. https://doi.org/10.1109/tie.2006.878355.

18. Tia H., Mancilla-David F., Ellis K., Muljadi E., Jenkins P. (2012) A Cell to Module to Array Detailed Model for Photovoltaic Panels. Solar Energy, 86 (9), 2695-2706. https://doi.org/10. 1016/j.solener.2012.06.004.

19. Hau C., Shen C. (1998) Comparative Study of Peak Power Tracking Techniques for Solar Storage System. APEC '98 Thirteenth Annual Applied Power Electronics Conference and Exposition. https://doi.org/10.1109/apec.1998.653972.

20. Elzein I., Petrenko Y. N. (2017) An Evaluation of Photovoltaic Systems MPPT Techniques under the Characteristics of Operational Conditions. Sistemnyi Analiz i Prikladnaya Informatika = System Analysis and Applied Information, (2), 30-38. https://doi.org/10.21122/23094923-2017-2-30-38 (in Russian).

21. Gow J. A., Manning C. D. (2009) Development of a Photovoltaic Array Model for Use in Power-Electronics Simulation Studies. IEE Proceedings - Electric Power Application, 146 (2), 193-200. https://doi.org/10.1049/ip-epa:19990116. 
22. Veerachary M., Senjyu T. (2002) Voltage-Based Maximum Power Point Tracking Control of PV System. IEEE Transactions on Aerospace and Electronic Systems, 38 (1), 262-270. https://doi.org/10.1109/7.993245.

23. Ibrahim H., Houssiny F. F., El-Din H. M. Z., El-Shibini M. A. (1999) Microcomputer Controlled Buck Regulator for Maximum Power Point Tracker for DC Pumping System Operates from Photovoltaic System. IEEE International Fuzzy Systems Conference Proceedings. https://doi.org/10.1109/fuzzy.1999.793274.

24. Villalva M., Gazoli J. R., Filho E. R. (2009) Comprehensive Approach to Modeling and Simulation of Photovoltaic Arrays. IEEE Transactions on Power Electronics, 24 (5), 1198-1208. https://doi.org/10.1109/tpel.2009.2013862.

25. Ovalle A., Chamorro H. R., Ramos G. (2012) Improvements to MPPT for PV Generation Based on Mamdani and Takagi-Sugeno Fuzzy Techniques. 2012 Sixth IEEE/PES Transmission and Distribution: Latin America Conference and Exposition (T\&D-LA). https://doi.org/ 10.1109/tdc-la.2012.6319085.

26. Alajmi B. N., Ahmed K. H., Finney S. J., Williams B. (2011) Fuzzy-Logic-Control Approach of a Modified Hill-Climbing Method for Maximum Power Point in Microgrid Standalone Photovoltaic System. IEEE Transactions on Power Electronics, 26 (4), 1022-1030. https://doi.org/ 10.1109/tpel.2010.2090903.

27. Lobaty A. A., Petrenko Yu., Abyfanas A. S., Elzein I. A. (2016) Impulse Control Hybrid Electrical System. Sistemnyi Analiz i Prikladnaya Informatika = System Analysis and Applied Information, (4), 46-52 (in Russian).

28. Sotnikova M., Zhabko N., Lepikhin T. (2012) Control Systems Analysis and Design Labs with Educational Plants. IFAC Proceedings Volumes, 45 (11), 212-217. https://doi.org/10.3182/ 20120619-3-ru-2024.00088.

29. Sotnikova M. V. (2012) Synthesis of Robust Control Algorithms with Predictive Models. Sistemy Upravleniya i Informatsionnye Tekhnologii [Management Systems and Information Technologies], 4 (50), 99-102 (in Russian).

30. Geyer T., Papafotiou G., Morari M. (2004) On the Optimal Control of Switch-Mode DC-DC Converters. Hybrid Systems: Computation and Control. $7^{\text {th }}$ International Workshop, HSCC 2004, Philadelphia, PA, USA, March 25-27, 2004. 342-356. https://doi.org/10.1007/978-3540-24743-2_23.

31. Mariethoz S., Beccuti A. G., Papafotiou G., Morari M. (2008) Sensorless Explicit Model Predictive Control of the DC-DC Buck Converter with Inductor Current Limitation. 2008 TwentyThird Annual IEEE Applied Power Electronics Conference and Exposition. https://doi.org/10. 1109/apec.2008.4522957.

32. Taheri A., Zhalebghi M. H. (2017) A New Model Predictive Control Algorithm By Reducing the Computing Time of Cost Function Minimization for NPC Inverter in Three-Phase Power Grids. ISA Transactions, 71, 391-402. https://doi.org/10.1016/j.isatra.2017.07.027.

33. Benghanem M. (2009) Low Cost Management for Photovoltaic Systems in Isolated Site with New I-V Characterization Model Proposed. Energy Conversion and Management, 50 (3), 748-755. https://doi.org/10.1016/j.enconman.2008.09.048.

34. Cameron P., Boyson W., Riley D. M. (2008) Comparison of PV System Performance-Model Predictions with Measured PV System Prediction. 33 ${ }^{\text {rd }}$ IEEE Photovolatic Specialists Conference. https://doi.org/10.1109/pvsc.2008.4922865.

35. Zhang H., Ji H., Ren J., Shan L., Gao Y. (2009) Research on MPPT Control and Implementation Method for Photovoltaic Generation System and its Simulation. 2009 IEEE $6^{\text {th }}$ International Power Electronics and Motion Control Conference. https://doi.org/10.1109/ipemc. 2009.5157747.

Received: 18 September 2018 Accepted: 9 January 2019 Published online: 30 September 2020 